\title{
RESEARCH
}

Open Access

\section{Effects of forest management on biomass stocks in Romanian beech forests}

\author{
O. Bouriaud ${ }^{1,2^{*}}$ (D, A. Don ${ }^{3}$, I. A. Janssens ${ }^{4}$, G. Marin ${ }^{2,5}$ and E.-D. Schulze 6
}

\begin{abstract}
Background: Forest management aims at obtaining a sustainable production of wood to be harvested to generate products or energy. However, the quantitative influence of forest management and of removals by harvest on biomass stocks has rarely been analysed on a large scale based on measurements. Two hypotheses prevail: management induces a reduction of wood stocks due to cuttings, versus no impact because of increased growth of the remaining trees.

Using data collected for 2840 permanent plots across Romania from the National Forest Inventory representing 2.5 Mha, we have tested to what extent different management types and treatments can influence the biomass stock and productivity of beech forests, and attempt to quantify these effects both on the short and long terms.

Three main types of beech forest management are implemented in Romania with specific objectives: intensive wood production in production forests, protection of ecosystem services (e.g. watersheds, avalanche protection) in protection forests, and protection of the forest and its biodiversity in protected forests. Production forests encompass two treatments differing according to the stand regeneration method: the age class rotation management and the group shelterwood management.

Results: We show that forest management had little influence on the biomass stocks at a given stand age. The highest stocks at stand age 100 were observed in production forests (the most intensively managed forests). Consequences of early cuttings were very short-termed because the increase in tree growth rapidly compensated for tree cuttings. The cumulated biomass of production forests exceeded that of protected and protection forests. Regarding the treatment, the group shelterwood forests had a markedly higher production over a full rotation period.

The total amount of deadwood was primarily driven by the amount of standing deadwood, and no management effect was detected.

Conclusions: Given the relatively low-intensity management in Romania, forest management had no negative impact on wood stocks in beech forests biomass stocks at large scale. Stand productivity was very similar among management types or treatments. However cumulated biomass in production forests was higher than in protection or protected forests, and differed markedly according to treatments with a higher cumulated biomass in shelterwood forests.
\end{abstract}

Keywords: Forest management, Forest productivity, Biomass stocks, National forest inventory

\footnotetext{
* Correspondence: obouriaud@gmail.com

${ }^{1}$ Integrated Center for Research, Development and Innovation in Advanced

Materials, Nanotechnologies, and Distributed Systems for Fabrication and

Control, Stefan cel Mare University, 720229 Suceava, Romania

${ }^{2}$ National Forest Inventory, National Research Development Institute for

Silviculture, Voluntari, Romania

Full list of author information is available at the end of the article
} 


\section{Background}

The influence of management on forest carbon stocks has been under discussion in the context of climate mitigation (Schulze et al. 2012) in the C-sequestration framework which stresses the need for increased carbon storage in terrestrial ecosystem, potentially conflicting with the increased need for wood supply in the future, bio-bases economy. Forest management could be one of the most influential drivers of forest carbon sequestration in the long term (Nabuurs et al. 2001; de Vries et al. 2006; Ciais et al. 2008; Schulze et al. 2018). However, its actual influence on the forest biomass stocks and productivity has been far less studied than that of climate or $\mathrm{CO}_{2}$ forcing (Ciais et al., 2008; Reyer et al. 2014; Erb et al. 2018).

The high diversity of management forms, but also other factors influencing forest productivity, such as site fertility, local climate etc., make the quantification of the influence of forest management very challenging. Management indeed takes a lot of different forms and intensities, and covers a great diversity of actions (Luyssaert et al. 2011; Duncker et al. 2012; Schall and Ammer 2013).

In order to study the influence of forest management on forest biomass and growth, the statistical replication of each management type should be sufficiently large. Only systematic sampling schemes, such as those implemented within national forest inventories (NFI), provide the required sample sizes for each management type, including protected forests. Large-scale estimations of biomass or carbon stocks have already been successfully derived from NFI data (e.g. Hall et al. 2001; Goodale et al. 2002; Pan et al. 2011) and provided important insights into large-scale forest biomass stock dynamics.

With a total area of the order of 2.5 Mha, common beech (Fagus sylvatica L.) is one of the dominant tree species in Romania and equals $\sim 14 \%$ of European beech forests area. Beech represents almost one-third of the Romanian growing wood stock. Another dominant species is spruce (Picea abies L.), but its management may not have the same variability as that of beech and we therefore did not assess the management impact for this species. Beech forests grow over the entire country and cover a wide diversity of management types and intensities. This species, therefore, offers the opportunity to investigate the influence of management on the biomass stocks and growth of forests, comparing differences between management types, intensities and harvest practices, within a relatively confined spatial domain. Studying these relations for one single species overcomes potentially confounding effects of differences in species mixture, and narrows the ecological conditions encompassed.

The forest management types of Fagus forests in Romania are differentiated according to the main objective selected for a given management unit: protected forests are forests where any form of harvest is excluded and whose objective is nature conservation; protection forests are forests located on steep slopes, protecting soils or watersheds. Harvest is possible, but limited, these forests being typically forests with restricted wood supply, thus this management has a low intensity. Production forests are primarily used for wood production and have generally a high intensity management. These management objectives are assigned through repeated 10-year management plans and represent the main objective prescribed for a given management unit. These three management types mainly differ in the level of harvest limitation: no harvest in protected forests, low intensity harvest in protection forests, and higher intensity harvest in production forests. The production management itself takes a great variety of forms, depending on the thinning regime and the harvest method (final felling), because the harvest influences the regeneration process hence the structure of the stand that results from it (Matthews 1989; Duncker et al. 2012). In short, the harvest can either promote a regular structure with a restricted difference in tree age (e.g. after clear-cutting and short-duration shelterwood), or, on the contrary, promote age and structural heterogeneity (e.g. after tree selection). These treatments therefore need to be distinguished as they subsequently involve a diversity of tendering and thinning operations.

Historically, the management type of a given stand has hardly changed over time since the 70 s as the classification into protection forest or protected forest depends on permanent site conditions (ex. accessibility, steep slopes, watershed) or stand features (ex. rare species, absence of cuttings).

Production forests are essentially managed according to three harvest and regeneration methods, referred to as treatments: age class, for even-aged forests; group shelterwood (or in short, shelterwood) based on creating gaps to promote un-even-aged structures; and selected tree cutting generating an irregular forest structure. In age class forests, the harvests are implemented by removing a prescribed fraction of the trees (one third, typically from the intermediate and lower layers) from the entire stand. In the shelterwood type, the trees are harvested by patches that generate small-size openings. Openings are widened by each successive harvest until the entire cover is removed. Age class and shelterwood do not strongly differ in the thinning intensity, they mostly differ in the way harvests and regeneration are implemented, which has potentially large consequences on the forest structure and stem density in young stages.

In Romania, stands are kept at rather high densities and with very long rotations compared to other countries (Bouriaud et al. 2016): thinnings are typically of low intensity and can (legally) be implemented only up to 
until $\sim 80$ years old, after which the stands enter the no intervention (dead period) till they reach 100 years of age. Given the duration of the regeneration cuttings, the final cut age can reach 160 years. In protection forests, thinnings are possible during the first $2 / 3$ of the rotation, after which only the so-called conservation harvests are allowed (salvage cuttings), at a maximum of $10 \%$ of the current standing volume. The harvest type is that of a shelterwood.

Two diverging hypotheses prevail concerning the influence of management on forest stocks and growth: i) forest management has a negative impact on forest stocks, because of the successive cuttings resulting in removing a share of the biomass (Nunery and Keeton 2010; Luyssaert et al. 2011; Naudts et al. 2016), or ii) management has no impact on forest stocks because cuttings are compensated by increased stand growth (Pretzsch 2005). The idea that management decreases forest productivity has been forwarded mainly by nature conservation promoters (Zeide 2001), but with little empirical support on the large scale (Noormets et al. 2015). Conversely, the position of forestry is that thinning concentrates resources in fewer, selected (the remaining) trees, which therefore grow faster. The consequences of thinning or partial cutting should therefore be mainly transitory, resulting in saw-tooth shaped time series of the aboveground biomass that builds up as a result of the faster growth of the remaining trees (Pretzsch 2009). However, the persistence and possible effects on the stand volume and growth remains poorly assessed on the large scale. Indeed, while tree-level responses of growth to variations in competition are well documented (Kunstler et al. 2011; Fichtner et al. 2012), the stand-level impact on the stocks and productivity has been mainly assessed by modeling (Thornley and Cannell 2000; Lafond et al. 2014), but has seldom been documented by direct measurements (Nunery and Keeton 2010; D’Amato et al. 2011).

The aim of this study is to analyse the impact of different management and treatment types on the biomass stock and productivity of beech forests in Romania with the hypothesis that growth compensates removals. Another aim is to determine if the cumulative biomass production -accounting for the wood biomass growth and removals of successive cuttings- along with the rotation cycle may be similar among the treatments because of these compensations.

\section{Methods}

The analysis of the impact of management on Fagus forests biomass stocks and growth requires estimating the stocks and the production (biomass increment over the last 5 years) for each management type (production, protection and protected) and treatments (age class, shelterwood and tree selection). The cuttings (biomass cut) on each plots also need to be assessed because it could strongly influence both stocks and growth. Once accounted, it enables the estimation of cumulated biomass production, living plus harvest, over the duration of a rotation.

\section{Forest management types and treatments}

In the context of NFI, the classification of the plots into forest management types was made according to the management plan. Plots were classified into the protected forests category only in the absence of harvest signs (skidder road, stumps, branch piles). In the absence of management plan information, the classification into protection forest can be based on the slope: all forests on slopes exceeding $35^{\circ}$ belong to protection forest type. The classification into treatment (age-class, shelterwood, tree selection) was based on the current forest structure and the regeneration method defined by the management plan. Age-class represents the most common treatment with over $63 \%$ of the beech-dominated forest area, followed by shelterwood with $36 \%$. Tree selection is very rare (less than $1 \%$ of the Fagus forest area) and will be neglected in the following analysis (see Hessenmöller et al. 2018). Differences in treatments originally reflected forest structure and usage. Before 1990 all forests were owned and managed by the State. Forest management does not differ between public and privately owned forests, both being regulated by the same rules. Ownership was therefore not considered in this study. Protection forest is $15 \%$ of the total Fagus-dominated area. These forests have been under protection the last 50 years and a great majority had not been subject to large-scale cuttings before given their inaccessibility.

\section{The inventory}

The analysis is based on the first cycle of the Romanian NFI. Inventory plots were filtered so that only pure or nearly pure beech stands were considered (the maximum admixture threshold was set at $10 \%$ of the total above-ground volume), which amounts to 2840 plots. The tree-level variables used were the tree diameter at breast height $(\mathrm{dbh}, \mathrm{cm})$ and the tree height $(h, \mathrm{~m})$. The plot-level data included the description of the stand management type and enabled the estimation of plot-level attributes such as the standing volume and the stand density.

The inventory is the first statistical forest inventory of Romania. It was initiated in 2006 and field measurements started in 2007. The field sampling of Fagus (ranging from 150 to $1650 \mathrm{~m}$ a.s.l.) was based on plots belonging to a systematic $4 \mathrm{~km} \times 4 \mathrm{~km}$ grid, resulting in a homogeneous set of data covering the entire country (Additional file 1: 
Figure S1). Thus our study that focuses on beech dominated forests covers an area of 2.47 Mha.

\section{Measurements on living trees}

For each tree we recorded the dbh using a calliper and height using a vertex hypsometer (Haglöf $A B$, Sweden). The tree-level woody aboveground biomass $(\mathrm{AB}, \mathrm{kg})$ was estimated based on the generic biomass equation for Central Europe (Wutzler et al. 2008) and based on both $\mathrm{dbh}$ and $h$ for predictions: $\mathrm{AB}=0.0523 \times \mathrm{dbh}^{2.12} \times h^{0.655}$.

\section{Deadwood measurements}

Two categories of deadwood were distinguished: lying deadwood and standing snags. The volume of decaying pieces was derived from the inventory of deadwood within the $200-\mathrm{m}^{2}$ plot. Each deadwood piece sampled was classified into one of the five decay classes based on a visual examination on the field. The diameter of each piece was measured at its middle, together with the length that falls into the inventory circle. Snags were recorded in the same manner as the living trees, with diameter and height measurements. Following Mund and Schulze (2006) and in the absence of specific measurements, wood density was assumed to decrease linearly from decay class 1 to class 5 , from 558 to 62 $\mathrm{kg} \cdot \mathrm{m}^{-3}$. The density used for class 1 was the same as that for living trees: $558 \mathrm{~kg} \cdot \mathrm{m}^{-3}$.

Branch piles were inventoried when they lay inside the inventory plot, and were attributed to similar decay classes as the lying deadwood. Two right-angle diameters and the top height of the pile were measured on the field so that the outer piles' volume was approached using the theoretical semi-volume of an ellipsoid (Woodall et al. 2013). The actual volume of wood inside the piles was estimated at the tenth of that of the pile since the packing ratio was not assessed in the field.

\section{Cuttings}

The recent cuttings were used to quantify the management intensity. Since the data available come only from the first NFI cycle, the cuttings can be evaluated only based on stumps. Stumps are classified according to their decomposition into four decay classes. Only recent stumps with no visible wood decay were considered in the analysis. Given the high rate of decay of beech wood (Kahl et al. 2017), the age of the stumps classified as recent is probably well below 10 years.

\section{Cumulated biomass}

The cumulated biomass was computed as the sum of the living stock and of the cumulative cuttings (i.e. cumulative sums from one age class to the next), all along the rotation, hence representing the cumulative biomass produced at each age classes during a rotation based on plots of different ages (replacement of space by time). They were estimated for each age class, management type and treatment by adding up the average living stock biomass and the cumulative average harvested biomass.

\section{Dendrochronological measurements}

Increment cores from 10 to 16 trees per plot were sampled from bark-to-pith at breast height, in order to estimate the growth rate of the trees in the plot. Trees were sampled outside the plot to avoid damage within the plot. The dbh of the trees sampled had to be larger or equal to the mean dbh within the plot. Tree growth is estimated based on the diameter and biomass increment during the past 5 years (Babst et al. 2014). To this end, species-specific models of biomass increment were fitted on the cored trees using the lme4 package of $\mathrm{R}$ (Bates et al. 2014). The species-specific models were in the form (Jucker et al. 2015; Bouriaud et al. 2016):

$$
\log \left(\Delta B_{i}\right)=\alpha_{j[i]}+\beta_{1} \log \left(B_{i}\right)+\beta_{2} h_{i}+\varepsilon
$$

where $\Delta B_{i}$ is the 5 -years biomass increment of tree $i$ in plot $j$ given its current biomass $B_{i}$ and top height $h_{i} ; \alpha_{j}$ is the random, plot-level intercept, parameters $\beta_{1}$ and $\beta_{1}$ are unknown and the residual variance $\varepsilon$ is assumed normally distributed.

The tree diameter over bark is measured directly in the field during the coring. The historical diameters are estimated by subtracting the width of the last 5 rings. Bark thickness growth is assumed to be proportional to the diameter growth in accordance with Bakker (2005). All samples were dried and sanded before being scanned at 1200 or 2400 dpi using a flatbed scanner depending on the condition of the samples and the width of the rings. The ring width series were measured as well as the distance to pith, when missing, using the C-Dendro suite (Cybis Elektronik \& Data AB Saltsjöbaden, Sweden). Absolute dating and potential measurement mistakes or missing rings were tracked and corrected using C-Dendro.

\section{Relative stand density index}

The relative density index (RDI) was computed in order to provide a quantitative description of the stem crowding independently from tree size and age, based on the self-thinning theory. High RDI indicates dense stands and low RDI open stands. The RDI has been thought for long to be a log-log linear relationship between the mean quadratic diameter and the stem density (Reineke 1933; Enquist and Niklas 2002), but recent studies have pointed out important curvature in the relationship (Charru et al. 2012). Moreover, the relationship varies among studies and seems to be influenced by site fertility. It therefore seemed important to fit a new Romania-specific model on 
the basis of the NFI data. The model was a curvilinear fit (Additional file 1: Figure S2) using the R package Quantreg (v5.33, Koenker 2017):

$\ln N=a+b \times \ln D_{g}+c \times\left(\ln D_{g}\right)^{2}$, where $a, b$ and $c$ are unknown parameters estimated for the 95th quantile.

\section{Dominant height}

Dominant height was used as a proxy for site fertility for its very low sensitivity to stem density and high correlation with stand productivity (Assmann 1970; Skovsgaard and Vanclay 2008). Here, dominant height was defined as the mean height of the four largest trees, estimated for each plot. The dominant height was subsequently modelled using a dominant height-age logistic model, fitted on the NFI data (Additional file 1: Figure S3) using the nls $\mathrm{R}$ function.

\section{Statistical methods}

The first hypothesis is that biomass stocks are not affected by management or treatments, even in the most intensive treatment type. The second hypothesis is that the productivity is not depressed on medium or long terms by successive cuttings, hence that intensely managed forests have a similar productivity level to that of low intensity forests.

The influence of forest management type and treatment on the aboveground biomass was tested using a multiple linear model $(\mathrm{mlm})$ where stand age, dominant height, stem density are independent variables, management type or treatment are categorical, fixed factors. The rationale of using a mlm model is that all variables and factors and their potential interactions are readily included in the model. The dependence of the aboveground biomass stock and of the productivity on factors, common to all forest types and treatments, was thus represented by the continuous variables while the effects of the management types and the treatments were represented by the categorical variables. A significant coefficient associated with a factor represents a significant influence of the factor on the biomass stock or the productivity.

Additionally, an ANOVA was performed to compare the biomass or productivity per management types and treatments. Type-II errors were computed in order to estimate the error risk of accepting the null hypothesis (that there are no significant differences).

A complementary test was made for situations where a group has a highly different number of plots, as in the case of protected and protection forest. The test was based on resampling the plots with replacement, such that groups have the same effective for mean and variance estimations.

All statistical analyses and models were made in $\mathrm{R}$ (3.3.0; R Development Core Team 2016).

\section{Results}

Forest management and stocks

Aboveground woody biomass increased with stand age across all management types and treatments to reach 300 t.ha $^{-1}$ at 100 years (Fig. 1). Up to this age, the biomass increase along stand age was very similar among management types and treatments in spite of their different cutting intensities (Fig. 2). Noticeably, the range and maximum values were also very similar (Table 1 ). The model showed no significant effect of the management type on the aboveground biomass before final harvest (Table 2).

Conformingly the ANOVA per age classes showed no significant influence of the forest management type on the aboveground biomass (Table 3), except for the age classes 30, 60 and 80 age classes, which showed an overall higher biomass on production forests than in protection forests despite the thinnings occurring in production forests at these ages. Furthermore, no significant effects were noticed during the 'dead period' theoretically without cuttings at $90-110$ years.

The tendency for reduced biomass stocks after 100 years in production forests indicates the effects of regeneration harvests. Comparing the biomass stocks over the entire production cycle (i.e. including the harvest age range 100-160 years), the protection stands had significantly more biomass (about $92 \mathrm{t} \cdot \mathrm{ha}^{-1}$ ) than production stands (Table 2).

Despite the cuttings, the biomass was very similar in age class and group shelterwood forests (Fig. 1) with no significant overall effect of the forest treatment on the aboveground woody biomass (Table 3). The biomass was indeed slightly but significantly lower in age class forests at stand age 30 (in the order of $-25 \mathrm{Mg} \cdot \mathrm{ha}^{-1}$ ) but higher

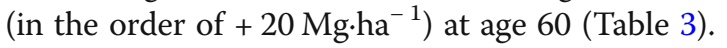

\section{Influence of management on production}

Stand production was quantified as the stand-level aboveground biomass increment over the last 5 years. Higher production in the $30-80$ years old range was observed for production forest due to taming and thinning (Fig. 3) compared to other management types. Despite the successive cuttings, the stand production of production forests remained at a level comparable or was even higher than that of protection (low cuttings) or protected (no cuttings) forests at stand ages exceeding 100 years old. The surge in growth at ages around 150 years corresponds to the harvest cuttings, which boost the growth of the remaining trees.

Stand production was primarily correlated to the standing biomass (Fig. 4). The rate of biomass increment was relatively equal throughout the observational network: $2.4 \%$ on average. The upper limit of production decreased with age in protection forests too. The $\mathrm{lm}$ 


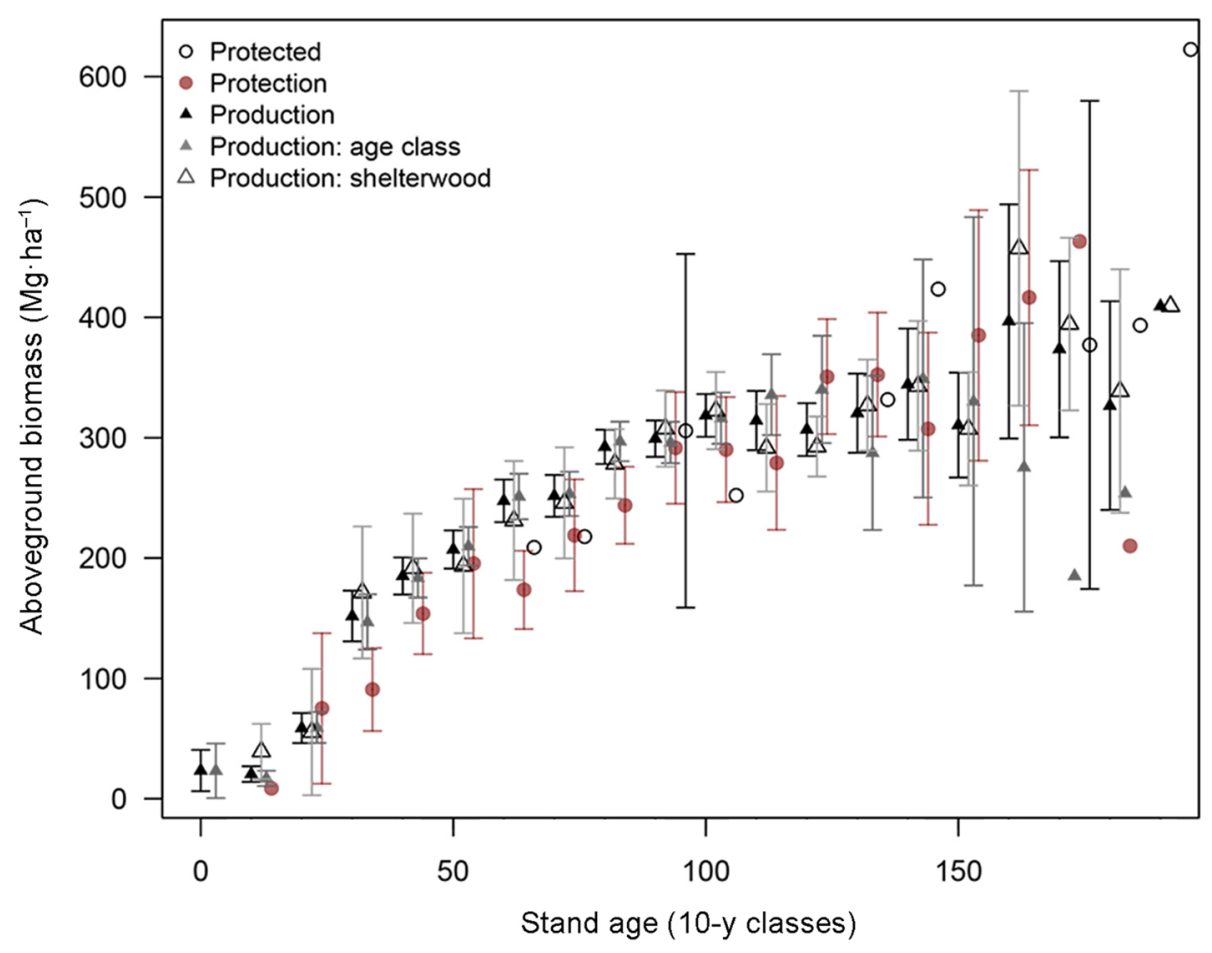

Fig. 1 Comparison of the standing biomass per age classes for the three different forest management types and treatments. A small shift on the $X$ axis for each group was introduced to avoid overlay. Bars represent 1 SD and are displayed only for groups larger than 5 plots. Significance of the difference in biomass among management types or treatments are displayed in Table 4
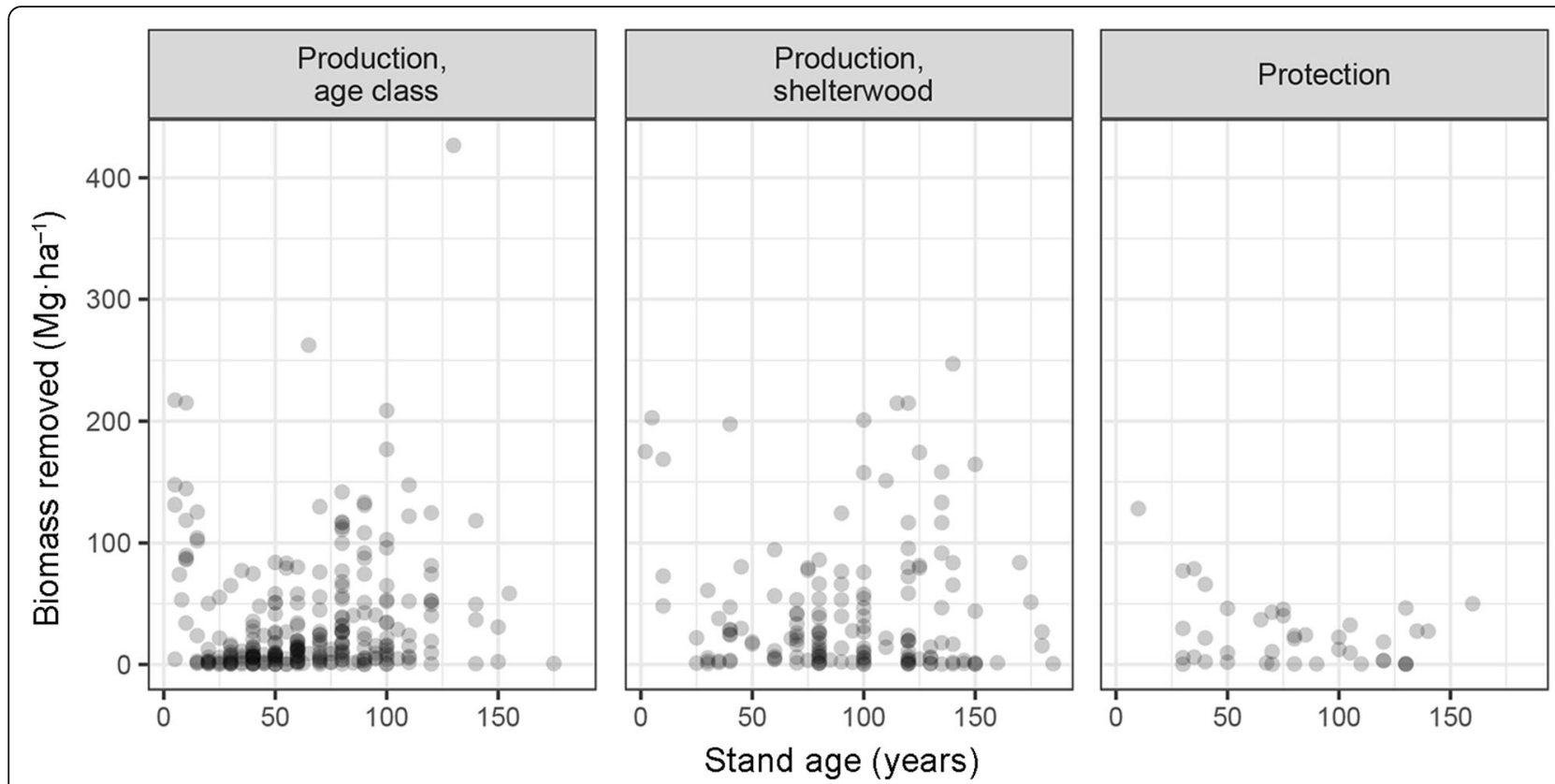

Fig. 2 Distribution of the biomass recently cut against stand age for production and protection forestsThere is one dot per plot. By definition of the management types, there are no cuttings in protected forests, which are thus not represented here 
Table 1 Number of plots, aboveground biomass per forest management type and forest treatment

\begin{tabular}{|c|c|c|c|c|c|c|c|}
\hline $\begin{array}{l}\text { Forest management } \\
\text { type }\end{array}$ & Treatment & Age range & $\mathrm{N}$ plots & $\begin{array}{l}\text { Mean age } \\
( \pm S D)\end{array}$ & $\begin{array}{l}\text { Mean AG biomass } \\
\left( \pm \text { SD) }\left(\mathrm{t}^{\left.-h a^{-1}\right)}\right.\right.\end{array}$ & $\begin{array}{l}\text { AG biomass } 3 d \\
\text { quantile }\left(t \cdot h a^{-1}\right)\end{array}$ & $\begin{array}{l}\text { Max AG biomass } \\
\left(\mathrm{t}^{-1} \mathrm{a}^{-1}\right)\end{array}$ \\
\hline \multirow[t]{3}{*}{ Protected } & & all & 36 & $123(47)$ & $341(175)$ & 422 & 792 \\
\hline & & $<100$ years & 17 & $79(21)$ & $245(108)$ & 298 & 456 \\
\hline & & $>100$ years & 20 & $160(24)$ & $423(182)$ & 483 & 792 \\
\hline \multirow[t]{3}{*}{ Protection } & & all & 431 & $95(36)$ & $271(161)$ & 371 & 871 \\
\hline & & $<100$ years & 251 & $70(25)$ & $222(137)$ & 302 & 613 \\
\hline & & $>100$ years & 180 & $129(17)$ & 339 (169) & 457 & 871 \\
\hline \multirow[t]{9}{*}{ Production } & All treatments & all & 2374 & $85(36)$ & $268(155)$ & 361 & 936 \\
\hline & & $<100$ years & 1696 & $68(26)$ & $246(141)$ & 337 & 936 \\
\hline & & $>100$ years & 642 & $128(17)$ & $321(168)$ & 431 & 928 \\
\hline & Age class & all & 1478 & $73(31)$ & $253(144)$ & 338 & 824 \\
\hline & & $<100$ years & 1291 & $66(26)$ & $241(137)$ & 330 & 772 \\
\hline & & $>100$ years & 187 & $122(15)$ & 329 (159) & 433 & 824 \\
\hline & Group shelterwood & all & 860 & $104(35)$ & $293(167)$ & 394 & 936 \\
\hline & & $<100$ years & 405 & $74(25)$ & $262(152)$ & 350 & 936 \\
\hline & & $>100$ years & 455 & $130(17)$ & $318(171)$ & 430 & 928 \\
\hline
\end{tabular}

model explained over $67 \%$ of the variance in production and showed that standing biomass, fertility, stem density and stand age were all significant drivers of the biomass production (Table 4). In contrast, the treatment was not a significant factor, nor was the number of trees recently removed or their cumulated biomass, showing that past cuttings, by thinnings or by harvests, have little influence on the current stand production.

Table 2 Parameters estimation and significance of the aboveground biomass model with forest management type as categorical variable before harvest (age $<100$ years) and with harvest (all data)

\begin{tabular}{lcccc}
\hline Parameters & Estimate & std error & $t$ value & $\operatorname{Pr}(>|t|)$ \\
\hline Before harvest: age $<100$ years & & & \\
$N=1863$, RMSE $=97.08, R^{2}=0.46$ & & & \\
Intercept (Production) & -71.056 & 8.864 & -8.016 & $1.91 \mathrm{e}-15$ \\
Protected & -9.75 & 23.725 & -0.411 & 0.681 \\
Protection & 5.528 & 6.787 & 0.814 & 0.415 \\
Age & 0.471 & 0.118 & 3.993 & $6.79 \mathrm{e}-05$ \\
Dominant height & 1.249 & 0.041 & 30.496 & $<2 \mathrm{e}-16$ \\
With harvest: no age filter & & & & \\
$N=2703$, RMSE = 113.30, $R^{2}=0.43$ & & & \\
Intercept (Production) & -76.142 & 8.311 & -9.161 & $<2 \mathrm{e}-16$ \\
Protected & 15.438 & 19.839 & 0.778 & 0.437 \\
Protection & 16.943 & 6.050 & 2.800 & 0.005 \\
Age & 0.257 & 0.074 & 3.472 & $5.25 \mathrm{e}-05$ \\
Dominant height & 1.323 & 0.036 & 36.764 & $<2 \mathrm{e}-16$ \\
\hline
\end{tabular}

Individual tree growth was, however, markedly improved at low stem densities. Radial growth was indeed significantly higher for trees growing in scarce stands (RDI $<0.92,0.92$ being the median RDI value over the network) as compared to higher density stands (Fig. 5): the mean ring width in stands with a lower relative density was on average $17 \%$ larger during the last 5 years than in stands with RDI $>0.92$, although the sampled stands of each category were of similar age.

Table 3 Parameters estimation and significance of the aboveground biomass model with treatment as categorical variable before harvest (age $<100$ years) and with harvest (all data)

\begin{tabular}{|c|c|c|c|c|}
\hline Parameters & Estimate & std error & $t$ value & $\operatorname{Pr}(>|t|)$ \\
\hline \multicolumn{5}{|c|}{ Before harvest: age $<100$ years } \\
\hline \multicolumn{5}{|c|}{$N=1608, \mathrm{RMSE}=96.99, R^{2}=0.46$} \\
\hline Intercept (Age class) & -84.616 & 10.124 & -8.358 & $<2 \mathrm{e}-16$ \\
\hline Shelterwood & -2.340 & 5.877 & -0.398 & 0.691 \\
\hline Age & 0.264 & 0.137 & 1.929 & 0.054 \\
\hline Dominant height & 1.237 & 0.045 & 27.350 & $<2 \mathrm{e}-16$ \\
\hline \multicolumn{5}{|c|}{ With harvest: no age filter } \\
\hline \multicolumn{5}{|c|}{$N=2212, \operatorname{RMSE}=110.76, R^{2}=0.42$} \\
\hline Intercept (Age class) & -91.614 & 9.519 & -9.625 & $1.4 \mathrm{e}-15$ \\
\hline Shelterwood & -8.830 & 5.342 & -1.653 & 0.099 \\
\hline Age & 0.122 & 0.093 & 1.311 & 0.190 \\
\hline Dominant height & 1.301 & 0.039 & 33.570 & $<2 \mathrm{e}-16$ \\
\hline
\end{tabular}




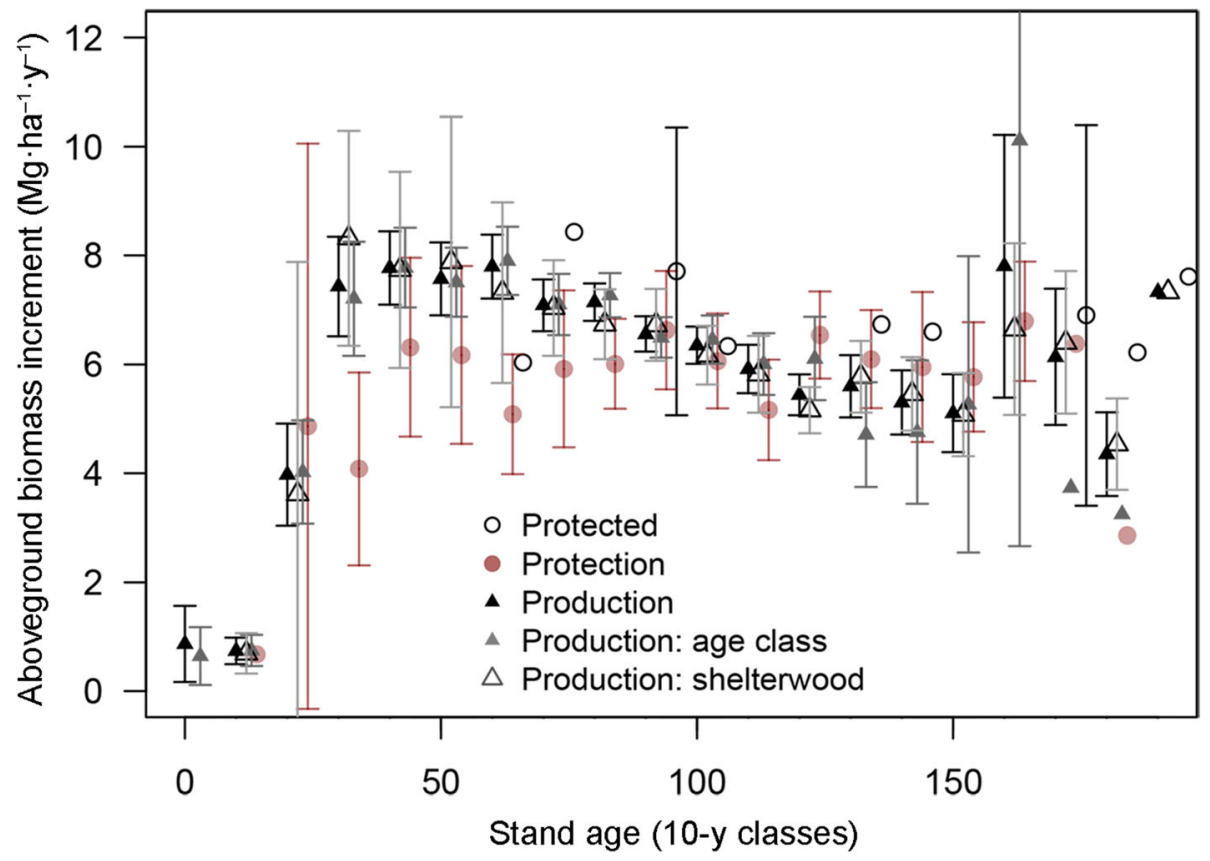

Fig. 3 Comparison of the biomass production per age classes for the three different forest management types and three treatmentsA small shift on the $\mathrm{X}$ axis for each group was introduced to avoid overlay. Bars represent 1 SD and are displayed only for groups larger than 5 plots

\section{Management and deadwood}

The total amount of downed or standing deadwood was not significantly different according to the management types or treatments because the variability within each category was very large (Table 5, Fig. 6). Likewise, the range of deadwood biomass was very comparable although the highest values were observed in protection forest.

The smaller number of observations in protected forests and the lack of regeneration in protected forests may have influenced these results. The plots were therefore randomly drawn from the population of plots in each category (production, protection and protected forests) in such a way that the number of plots is equal in all categories. This resampling test confirmed that the mean values per category and dynamics were similar among treatments and not caused by the imbalanced number of plots (Additional file 1: Figure S4).

The contribution of the branch piles and stumps in managed forests was always small compared to that of lying dead trees (Table 5). The biomass of standing dead trees was similar to that of lying deadwood, with no significant effects of management and treatments but much larger standing deadwood stocks in protected forests only. The relation between total deadwood and living biomass was very weak $(R=0.04)$ and not significant.

\section{Rotation-cycle cumulative biomass production}

The total wood production before final harvest was estimated by adding the average living stock to the average cumulative harvested biomass (Fig. 7) per management types, treatments and age class. The resulting average cumulative amount of produced biomass reached 450 $\mathrm{t} \cdot \mathrm{ha}^{-1}$ at 100 years (before harvests) in production forest against $380 \mathrm{t} \cdot \mathrm{ha}^{-1}$ in protection forest, but this difference was reduced towards the end of the cycle (after 140 years). Cumulated biomass differed markedly between treatments (Fig. 7 right): the mean value exceeded 600 t.ha ${ }^{-1}$ after 140 years in group shelterwood while it remained below $500 \mathrm{t} \cdot \mathrm{ha}^{-1}$ in age class forests. At the end of the rotation cycle, all biomass is harvested in age class forests, contrary to all the other treatments where permanent cover is maintained. Thus, the average aboveground biomass over a rotation cycle was $9 \%$ higher in production forest than in low intensity managed forests or in protected forests.

\section{Discussion}

We found that forest management type had no significant effects on the aboveground living biomass stocks of beech forests across Romania within a production cycle, despite important effects on the stand density and structure, and the temporarily significant reduction in stocks. More intensively managed forests had an equal or even higher stock at a given age than protected forests. Productivity was slightly higher in forests used for wood production throughout the production cycle, but overall no statistically significant effects of management type and management intensity on the standing stock and the 

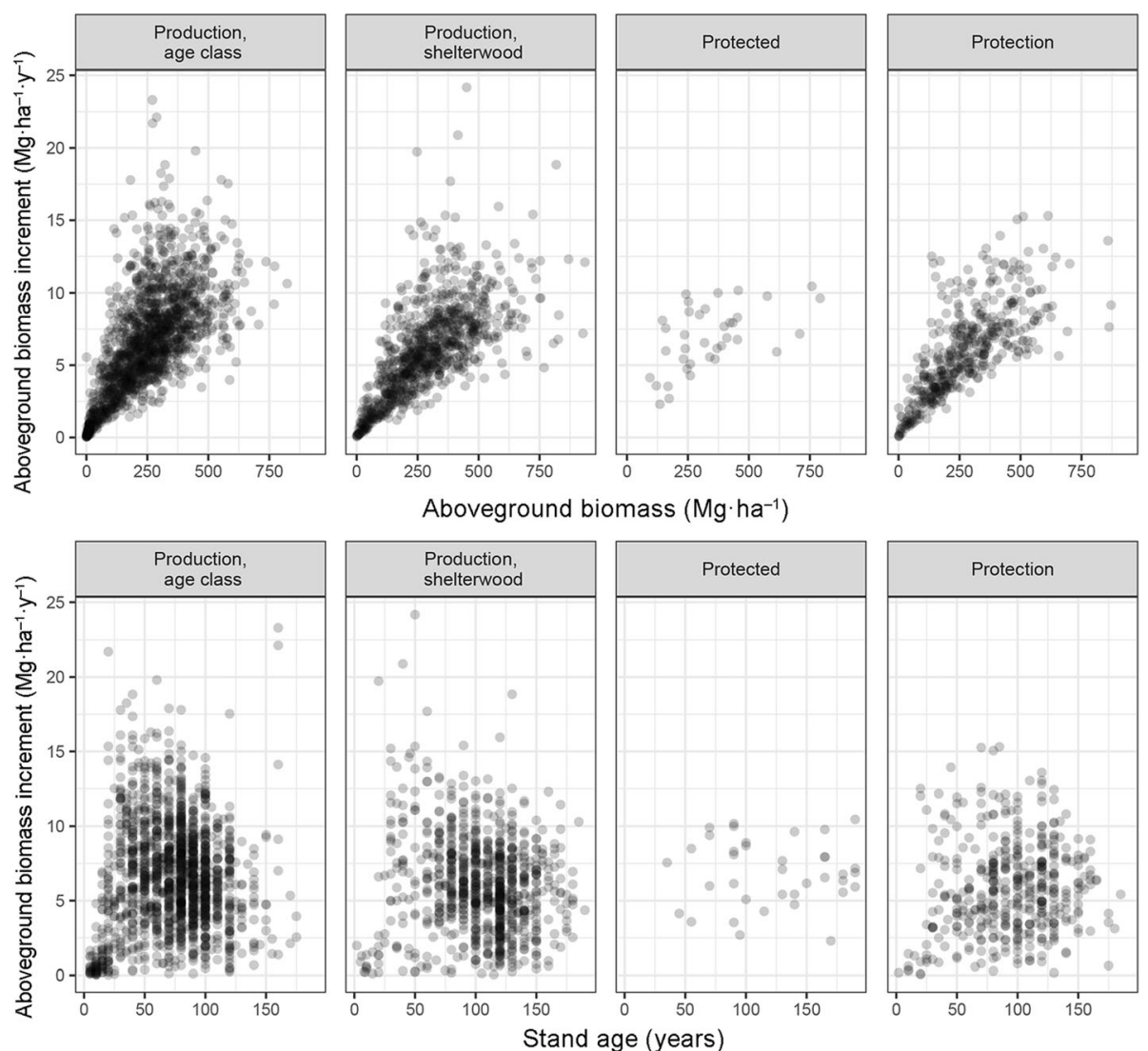

Fig. 4 Relation between the production (mean AG biomass increment over the last 5 years) and the AG biomass (up) or the stand age (down) according to the forest management type and treatment

production of the forests were detected at country scale. The cumulative amount of biomass produced at the end of a cycle was, however, higher in production forest, particularly in group shelterwood, than in protected forests.

\section{Forest management type}

Management type had limited impact on beech forest biomass stock and productivity, except for the obvious decrease in stocks when regeneration harvests start after 100 years. More intensively managed forests were indeed having a higher stock at 100 years than protected stands. These results at country scale (2.47 Mha) are in agreement with Nunery and Keeton (2010) -though based on simulations only- and references herein, De Simon et al. (2012) and Schaedel et al. (2017), suggested few consequences of forest management on the long-term biomass stocks. Our results are also in agreement with the fact that, on an even larger scale, there was an increase of the European forest biomass and a strong relationship between forest biomass and productivity during the last 50 years, in spite of their intensive use (Ciais et al. 2008). In the short term, however, in agreement with Keeling and Phillips (2007), productivity was strongly related to the standing biomass, with a rate being surprisingly stable through management types and treatments.

Recent cuttings were not found to affect productivity. These results are in agreement with Herbst et al. (2015) who showed that carbon fluxes measured using eddy covariance (particularly, the net ecosystem productivity rates) and biometric methods did not differ significantly between an unmanaged and a managed stand of beech in Germany. For other tree species also, stand productivity decreases only slightly even at high thinning intensity (Assmann 1970). Using Eddy covariance to measure $\mathrm{CO}_{2}$ exchange between beech forests and the atmosphere, Granier et al. (2008) and Pilegaard et al. (2011) reported no effect of thinning on the net ecosystem $\mathrm{CO}_{2}$ fluxes over beech stands, supporting the fact that productivity is not necessarily affected (reduced) by thinning.

The positive effects of management on individual tree growth are well documented for beech (Le Goff and Ottorini 1999; Pretzsch 2005 and references herein; van der Maaten 2013) and seem universal (Juodvalkis et al. 2005; Zeide 2005; Zhou et al. 2013), but are much less obvious at stand level. Here, we observed that stands with a lower density had a larger individual growth, in 
Table 4 Model of the productivity (5-years aboveground biomass increment, $\mathrm{Mg}_{\mathrm{h}} \mathrm{h}^{-1} \cdot \mathrm{y}^{-1}$ ) as a function of the dominant height, the stem density, the stand age and the forest treatment, analysed for production forest only before harvest

\begin{tabular}{|c|c|c|c|c|}
\hline Parameter & Estimate & std error & $t$ value & $\operatorname{Pr}(>|t|)$ \\
\hline \multicolumn{5}{|c|}{ Model 3: Productivity $=\mathrm{f}$ (treatment, dominant height, age, stem density) } \\
\hline \multicolumn{5}{|c|}{$N=1530$, RMSE $=1.851, R^{2}=0.647$} \\
\hline tercept & 2.056 & 0.307 & 6.694 & $3.04 \mathrm{e}-11$ \\
\hline reatment: Shelterwood & -0.013 & 0.111 & -0.120 & 0.904 \\
\hline boveground biomass & 0.016 & $4.9 e-04$ & 32.252 & $<2 \mathrm{e}-16$ \\
\hline ominant height & 0.009 & $1.1 \mathrm{e}-03$ & 5.184 & $4.77 \mathrm{e}-16$ \\
\hline Stem density & 0.001 & $8.9 e-05$ & 16.171 & $<2 \mathrm{e}-16$ \\
\hline tand age & -0.038 & $3.1 \mathrm{e}-03$ & -12.388 & $<2 \mathrm{e}-16$ \\
\hline \multicolumn{5}{|c|}{$\begin{array}{l}\text { Model 4: Productivity }=f \text { (forest management type, age, stem density, } \\
\text { removal) }\end{array}$} \\
\hline \multicolumn{5}{|c|}{$N=1530, \mathrm{RMSE}=1.847, R^{2}=0.647$} \\
\hline Intercept & 2.042 & 0.308 & 6.637 & $0.00258 * *$ \\
\hline reatment: Shelterwood & -0.018 & 0.111 & -0.158 & 0.874 \\
\hline Aboveground biomass & 0.016 & $5.1 e-04$ & 31.759 & $<2 \mathrm{e}-16^{* * *}$ \\
\hline Dominant height & 0.009 & $1.1 e-03$ & 8.118 & $3.86 \mathrm{e}-07 * * *$ \\
\hline Stem density & 0.001 & $8.9 e-05$ & 16.190 & $<2 \mathrm{e}-16^{* * *}$ \\
\hline Stand age & -0.038 & 0.111 & -12.394 & $<2 \mathrm{e}-16^{* * *}$ \\
\hline Biomass removed & 0.002 & 0.002 & 0.825 & 0.410 \\
\hline
\end{tabular}

agreement with the principle that productivity is concentrated over fewer, selected trees. This can be explained by the short-term increase of light interception and light use efficiency of the remaining trees in thinned stands (Granier et al. 2008), in combination with the ability for lateral growth of the crown of the remaining trees (Pouderoux et al. 2001). The highly dynamic growth of beech enables this species to rapidly close openings (Collet et al. 2001), also upon thinning (Pouderoux et al. 2001)

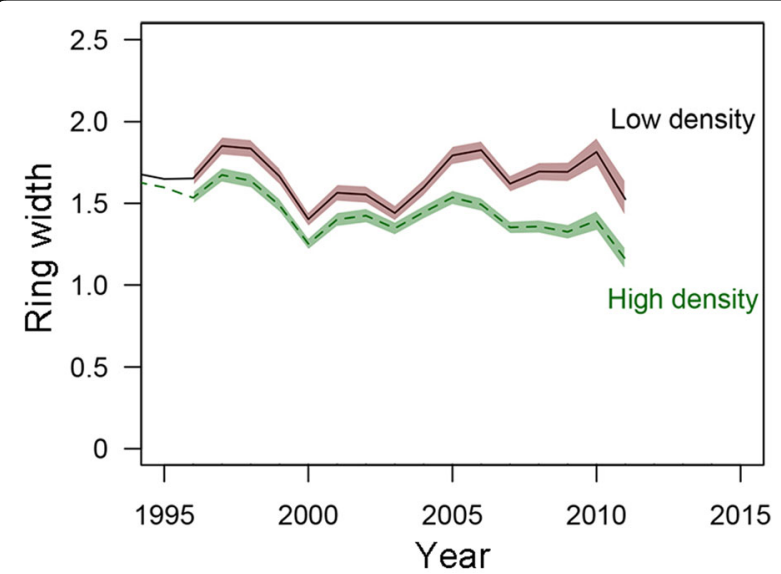

Fig. 5 Average ring width of the trees growing in stands with low stem density $(\mathrm{RDI}<0.92)$ or high density $(\mathrm{RDI}>0.92)$. Bands represent the confidence interval of the mean $( \pm 2 \mathrm{SD})$ where the leaf area index can reach pre-thinning values in a matter of three years even after a $40 \%$ decrease (Bouriaud 2003). Besides reducing vulnerability to drought thanks to a reduced rain interception and transpiration, thinning was also shown to prolong growing season's duration of beech stands (van der Maaten 2013).

These responses explain the apparent paradox, whereby the productivity was primarily related to the standing biomass, yet the influence of recently removed biomass was not significant, nor that the management type or the treatment significantly affected the standing biomass or productivity. Overall, tree stems contain very little nitrogen (Augusto et al. 2008), and therefore wood nitrogen losses due to thinning and stem removal are very likely easily compensated by atmospheric $\mathrm{N}$ deposition. The situation might be different for phosphorous and potassium, whose concentrations in stems are not negligible (Netzer et al. 2017) and whose export during thinning might exceed atmospheric inputs. In regions with young, fertile soils, potassium and phosphorous release from mineral weathering probably replenishes their stocks. In sandy areas, however, sustained removal of potassium and phosphorous in production forests may negatively affect tree growth, albeit only in the long term.

\section{Forest treatment}

Romanian beech forests typically regenerate naturally, and the stem density starts at very high values at low stand ages (Additional file 1: Figure S3), especially for even-aged stands. Tendering and thinning operations subsequently reduce the stem density, but the observed effects of the thinnings on biomass stocks or productivity were highly transient and no visible relation was observable between the recent cuttings and the standing biomass (Fig. 2). The average intensity of forest management is low in Romania, compared to other countries such as Germany (Bouriaud et al. 2016) with a strong deficiency in tendering, and thinning intensities being only frequency half that of Germany. Nonetheless, the relative stand density index RDI was below 0.92 for $50 \%$ of the stands and below 0.87 for over $25 \%$ of the stands in production forests, which means that management had a visible effect on the stand structure. The higher productivity at ages $<100$ observed in production forests as compared to protection or protected forests may have resulted from the stimulating effect of the tendering and thinning, which were shown to have long-lasting and large-scale stimulating consequences (Bouriaud et al. 2016; Zhou et al. 2013). The inter-tree competition for light was indeed found to be the strongest amongst trees growing in monocultures (Jucker et al. 2014) where canopy structure cannot avoid competitive inhibition. 
Table 5 Mean biomass (t per hectare \pm 1 SD) of deadwood per management types and treatments

\begin{tabular}{|c|c|c|c|c|c|}
\hline \multirow[t]{2}{*}{ Management type } & \multirow[t]{2}{*}{ Protected } & \multirow[t]{2}{*}{ Protection } & \multicolumn{3}{|l|}{ Production } \\
\hline & & & Total production & Age class & Shelterwood \\
\hline$N$ plots & 36 & 391 & 2382 & 1481 & 866 \\
\hline stump & 0 & $0.13 \pm 0.36$ & $0.20 \pm 0.46$ & $0.20 \pm 0.46$ & $0.21 \pm 0.46$ \\
\hline branch piles & 0 & $0.01 \pm 0.17$ & $0.16 \pm 1.66$ & $0.14 \pm 1.59$ & $0.18 \pm 1.76$ \\
\hline lying & $5.64 \pm 11.56$ & $5.67 \pm 15.53$ & $4.04 \pm 12.01$ & $3.34 \pm 11.17$ & $5.13 \pm 13.11$ \\
\hline Total downed & $5.64 \pm 11.56$ & $5.82 \pm 15.57$ & $4.40 \pm 12.21$ & $3.64 \pm 11.26$ & $5.64 \pm 13.56$ \\
\hline Standing deadwood & $16.72 \pm 33.00$ & $6.91 \pm 16.99$ & $4.62 \pm 13.92$ & $3.89 \pm 12.11$ & $5.86 \pm 16.51$ \\
\hline Total & $22.36 \pm 38.21$ & $12.72 \pm 26.27$ & $9.01 \pm 19.61$ & $7.53 \pm 17.21$ & $11.50 \pm 22.91$ \\
\hline
\end{tabular}

Competition is a strong factor controlling tree growth and is avoided primarily by thinning. In Romania, forest stands enter by law into a 25-years 'dead period' with no cuttings at around 100 years (Schulze et al. 2014; Bouriaud et al. 2016). The associated increase of competition seems to have visible effects at stand scale by levelling off productivity. The high tolerance to shade of beech and its great canopy plasticity (Pretzsch 2014) may create the conditions for stagnation (decrease in stand-level productivity at high stand density), which is eventually followed by natural mortality. Beech was indeed shown to survive to suppression (i.e. remain in the shade of dominant and codominant trees) several decades (Peters 1997). Nevertheless, we observed more natural mortality (standing dead trees biomass) in less intensively or unmanaged stands. The distribution of snag biomass
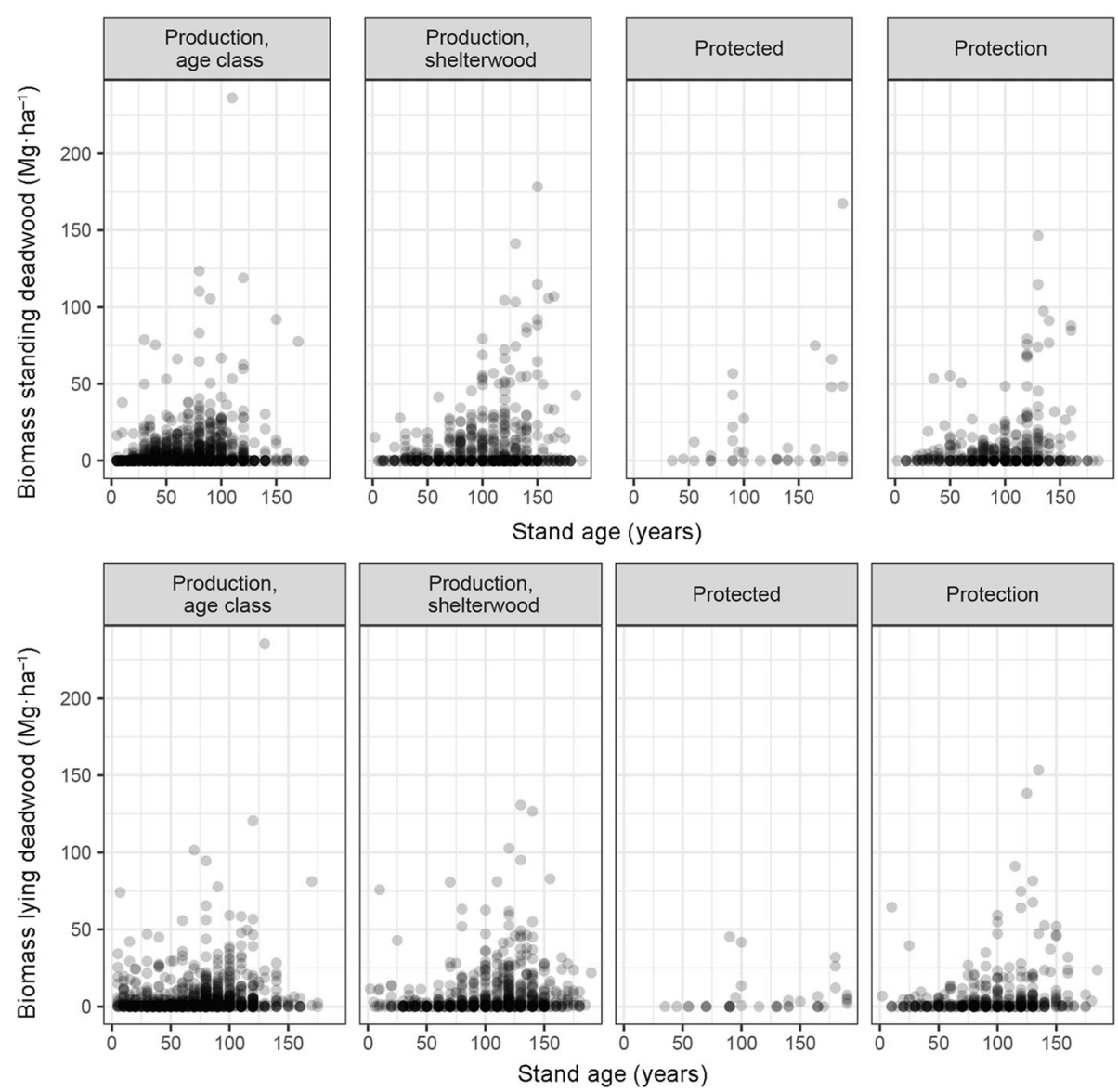

Fig. 6 Relation between the standing deadwood biomass (up) or lying deadwood biomass (down) and the stand age 

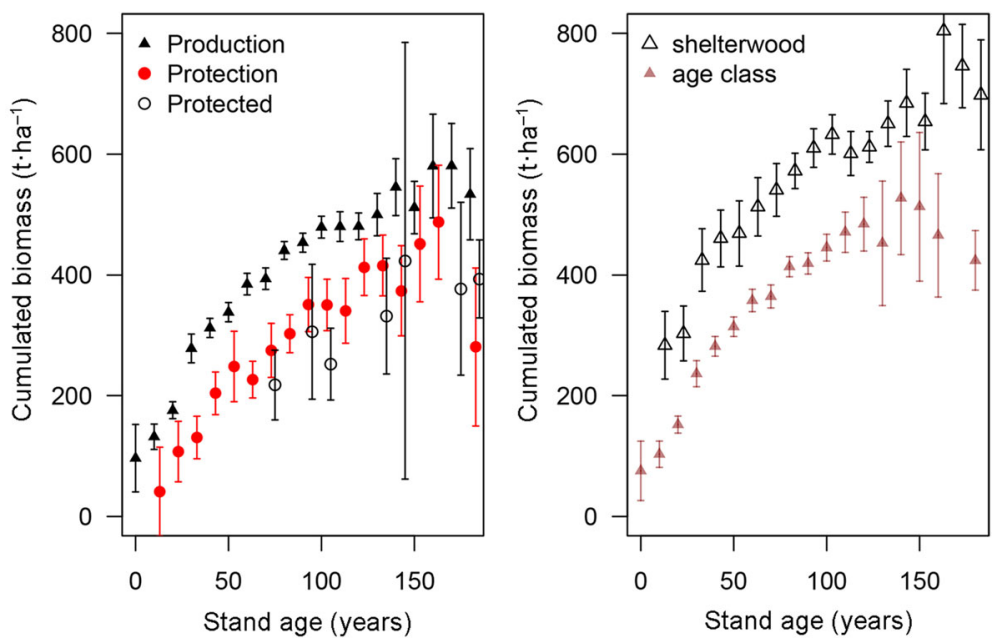

Fig. 7 Biomass accumulation curves (standing plus cuttings) per forest management types (left) and treatments (right)

shows a strong decline in age class forest beyond age 100, while snag biomass increases in unmanaged forest at ages $>100$ years. Apparently, snags are harvested, or destroyed for working safety in managed forests at harvesting age. In unmanaged forest, most trees die due to fungal infection, mainly by Fomes fomentaria (Purahong et al. 2014) at an age of about 150 to 250 years (Schulze 2018).

The lying deadwood biomass exhibited low values across the entire observational network. We found $77 \%$ $\left(\sim 2 \mathrm{t} \cdot \mathrm{ha}^{-1}\right)$ more standing deadwood in protected forests than in production forests and more than three times as much standing dead biomass in protection forests. The low amounts of downed or lying deadwood were probably attributable to fast decomposition. Assuming a 50\% C concentration, the deadwood pools contained between 3.5 and $11.2 \mathrm{Mg} \cdot \mathrm{C} \cdot \mathrm{ha}^{-1}$, which remains within the range of values encountered in unmanaged beech stands in Germany (Mund 2004; Mund and Schulze 2006) and Italy (De Simon et al. 2012). Very high deadwood biomass may be observed in wind-throw patches in protected oldgrowth forests but such a situation was not encountered in the entire inventory network.

Our study did not cover the belowground stocks, for which dedicated measurements and allometry models are lacking. It can be hypothesized that forest management in Romania has a reduced influence on these stocks since low level disturbance was shown to have little effects on the soil C pool (De Simon et al. 2012) and the effects of harvests on below-ground $C$ are temporary (Nave et al. 2010). Given the importance of the soil $\mathrm{C}$ pool, which has approximately the same size as the aboveground $\mathrm{C}$ pool for Fagus forests (De Simon et al. 2012 and references herein), further studies are needed to obtain a complete picture of the belowground components.

\section{Implications for forestry}

Our results show that under the current management in Romania beech forests can sustain cuttings at young stages without reducing their standing stocks and productivity at maturity. The amount of cumulative biomass, however, proved that the stands used for wood procurement have an excess production of over $100 \mathrm{t}^{-h^{-1}}(\sim 50$ $\mathrm{Mg} \mathrm{C} \cdot \mathrm{ha}^{-1}$ ) compared to forest stands with protective function. The biomass removed is therefore more than compensated by the accelerated growth of the remaining trees. Similarly, Pretzsch (2005) reports from long-term experimental plots a higher cumulative volume in heavily thinned stands than in low-intensity thinned stands for beech. More wood obtained during the rotation has important implications for the active contribution of forest stands to climate change mitigation through fossil fuel substitution (Birdsey and Pan 2015). It has been hypothesized that primary forests tend to store more carbon than managed forests (McKinley et al. 2011), but, as underlined by several previous works, managed forests can have a greater contribution to reducing the atmospheric $\mathrm{CO}_{2}$ once the substitution wood products and biomass for energy are accounted for (Schlamadinger et al. 1997; Fahey et al. 2010; Birdsey and Pan 2015).

In face of global environmental changes, the recommendations for silvicultural actions are to give priority to actions that can increase tree vigour, such as the early selection of future trees (Hemery 2008). The implementation of a pro-active forest management more adapted to climate changes seems to be unfortunately rather challenging due to institutional locks (Bouriaud et al. 2015; Sousa-Silva et al. 2018). Our results suggest that a reasonable silviculture should be envisaged that does not compromise $\mathrm{C}$ storage targets (Thornley and Cannell 2000; Garcia-Gonzalo et al. 2007; D'Amato et 
al. 2011). Decreasing the management intensity in production forest results in dense and closed canopy and a repression of light-demanding species, thus reducing plant biodiversity. Given the tendency of beech forests to be monospecific and with the view of promoting species diversity, silvicultural interventions are necessary to help less competitive species in admixture (Petrițan et al. 2017). Climate change and nitrogen deposition were not studied here but could have strong impacts on productivity. Positive trends in growth were indeed widely reported in Europe for Fagus (Dittmar et al. 2003; Aertsen et al. 2014), which are probably attributable to these factors. While these trends are likely not to alter the compensation of cuttings by the increased growth of remaining trees, the cutting intensity needs adaptations to the current growth rates. More frequent and intense droughts could however reverse the trends since Fagus is particularly responsive to drought (Scharnweber et al. 2011), and signs of inflections were already reported (Bontemps et al. 2010). The consequences for the stock and $\mathrm{C}$ pools are much more difficult to predict: higher mortality and increasing disturbance frequency could counterbalance the improved productivity of the stands.

Though this would require more research, there are clues that the conclusions drawn here on Fagus forests can be extended, to the least, to other forests dominated by a shade-tolerant species. The positive reaction of trees to thinnings of various intensity (Wallentin and Nilsson 2011), the dynamic of gap closure and recruitment are indeed general mechanisms that allow the rapid compensation of biomass losses caused by cuttings.

\section{Conclusions}

Our results confirm the hypothesis that forest management, despite its successive cuttings and modifications of stand structure, has temporary effects that does not reduce the biomass stocks on the long term and on a large scale in Fagus forests. Conversely, the cumulated biomass, which represents the total amount of biomass produced, was higher in managed forests. Noticeably, the management intensity in Romania is low compared to other European countries. These results are probably limited to forests where the cutting intensity and frequency is sufficiently low so as to enable a reconstitution of the stocks. Deadwood stocks were not related to management either, with a small contribution of the branch piles and stumps in managed forests. Forests therefore can contribute to the effort of climate mitigation by both storing biomass and contributing to the provision of major ecosystem services such as wood production through management.

\section{Additional file}

Additional file 1: Figure S1. Location of the NFI plots used for the analysis. Plots were selected based on the species composition such that beech represents at least $90 \%$ of the aboveground volume. Figure S2. Relationship between the stand density $\left(\mathrm{N} \cdot \mathrm{ha}^{-1}\right)$ and the mean quadratic diameter $(\mathrm{cm})$ of the stands plotted for pure beech stands from the NFI network. Figure S3. Dominant height model fitted to the beech stands sampled, all management types included. Figure S4. Relation between the productivity (mean aboveground biomass increment over the last 5 years) and the stands' dominant height (up) and stem density (down) according to the forest management type and treatment. Figure S5. Comparison of the mean deadwood biomass stock per management type and treatment against stand age. The confidence bands represent the mean and 2 standard deviation interval over 200-iterations resampling that aims at compensating for the difference in plot number between categories: 35 plots are randomly selected with replacement within each category, 36 being the number of plots in the less replicated category (protected forests, cf. Table 1). Table S1. Variance analysis (ANOVA) table for aboveground biomass with management type as factor (left) or treatment as factor (right). Df values are residuals' degrees of freedom (DOCX $2448 \mathrm{~kb}$ )

\section{Abbreviations}

a.s.l: Above see level; ANOVA: Analysis of variance; C: Carbon (element); dbh: Diameter at breast height; h: Total tree height; Im: Linear model; NFI: National Forest Inventory; R: Correlation coefficient; RDI: Relative density index; t: Tonne (metric)

\section{Acknowledgements}

We would like to thank Gheorghe Stefan for his invaluable technical support, the editor and anonymous reviewers who helped improving sensibly this article.

\section{Funding}

The research leading to these results received funding from the European Union Seventh Framework Program (FP7/2007-2013) under grant agreement $n^{\circ}$ 244122. OB acknowledges support by a grant of the Romanian National Authority for Scientific Research, CNCS-UEFISCDI, project number PN-II-IDPCE-2011-3-0781. IAJ acknowledges support of the University of Antwerp Research Council through its Methusalem program.

\section{Availability of data and materials}

The datasets analysed during the current study are subjected to approval. They can be available from the corresponding author on reasonable request.

Authors' contributions

OB analysed the data and wrote the manuscript. EDS made substantial contributions to the conception and design, the interpretation of data and writing of the manuscript. All authors read and approved the final manuscript.

Ethics approval and consent to participate

Not applicable.

Consent for publication

Not applicable.

Competing interests

The authors declare that they have no competing interests.

\section{Author details}

${ }^{1}$ Integrated Center for Research, Development and Innovation in Advanced Materials, Nanotechnologies, and Distributed Systems for Fabrication and Control, Stefan cel Mare University, 720229 Suceava, Romania. ${ }^{2}$ National Forest Inventory, National Research Development Institute for Silviculture, Voluntari, Romania. ${ }^{3}$ VTI, Braunschweig, Germany. ${ }^{4}$ Department of Biology, University of Antwerpen, Universiteitsplein 1, 2610 Wilrijk, Belgium. ${ }^{5}$ Faculty of Silviculture and Forest Engineering, Transilvania University of Brasov, Str. Sirul Beethoven, nr. 1, 500123 Brasov, Romania. ${ }^{6}$ Max-Planck Institute for Biogeochemistry, PO Box 100164, 07701 Jena, Germany. 
Received: 8 December 2018 Accepted: 22 March 2019

\section{Published online: 04 April 2019}

\section{References}

Aertsen W, Janssen E, Kint V, Bontemps J-D, Van Orshoven J, Muys B (2014) Longterm growth changes of common beech (Fagus sylvatica L.) are less pronounced on highly productive sites. Forest Ecol Manag 312:252-259.

Assmann E (1970) The principles of forest yield study, vol 45. Pergamon Press, Oxford, pp 160-163 pp.

Augusto L, Meredieu C, Bert D, Trichet P, Porté A, Bosc A, Lagane F, Loustau D, Pellerin S, Danjon F, Ranger J (2008) Improving models of forest nutrient export with equations that predict the nutrient concentration of tree compartments. Ann For Sci 65:808.

Babst F, Bouriaud O, Alexander R, Trouet V, Frank D (2014) Toward consistent measurements of carbon accumulation: a multi-site assessment of biomass and basal area increment across Europe. Dendrochronologia 32(2):153-161.

Bakker JD (2005) A new, proportional method for reconstructing historical tree diameters. Can J For Res 35(10):2515-2520.

Bates D, Maechler M, Bolker B, Walker S (2014) Ime4: linear mixed-effects models using Eigen and S4. R package version 1:1-7.

Birdsey R, Pan Y (2015) Trends in management of the world's forests and impacts on carbon stocks. Forest Ecol Manag 355:83-90.

Bontemps J-D, Hervé J-C, Dhôte J-F (2010) Dominant radial and height growth reveal comparable historical variations for common beech in North-Eastern France. Forest Ecol Manag 259(8):1455-1463.

Bouriaud L, Marzano M, Lexer M, Nichiforel L, Reyer C, Temperli C, Peltola H, Elkin C, Duduman G, Taylor P, Bathgate S, Borges G, Clerkx S, Garcia-Gonzalo J, Gracia C, Hengeveld G, Kellomäki S, Kostov G, Maroschek M, Muys B, Nabuurs G-J, Nicoll B, Palahí M, Rammer W, Ray D, Schelhaas M-J, Sing L, Tomé M, Zell J, Hanewinkel M (2015) Institutional factors and opportunities for adapting European forest management to climate change. Region Environ Change 15(8):1595-1609.

Bouriaud O (2003) Analyse fonctionnelle de la productivité du hêtre: influences des conditions de milieu, de la structure du peuplement et du couvert, effets de l'éclaircie. Thèse de Doct. en Sciences forestière, ENGREF, p 240.

Bouriaud O, Marin G, Bouriaud L, Hessenmöller D, Schulze E-D (2016) Romanian legal management rules limit wood production in Norway spruce and beech forests. Forest Ecosyst 3:20.

Charru M, Seynave I, Morneau F, Rivoire M, Bontemps J-D (2012) Significant differences and curvilinearity in the self-thinning relationships of 11 temperate tree species assessed from forest inventory data. Ann For Sci 69(2):195-205.

Ciais P, Schelhaas M-J, Zaehle S, Piao SL, Cescatti A, Liski J, Luyssaert S, Le-Maire G, Schulze E-D, Bouriaud O, Freibauer A, Valentini R, Nabuurs G-J (2008) Carbon accumulation in European forests. Nat Geosci 1:425-429. https://doi. org/10.1038/ngeo233.

Collet C, Lanter O, Pardos M (2001) Effects of canopy opening on height and diameter growth in naturally regenerated beech seedlings. Ann For Sci 58(2): 127-134.

D'Amato AW, Bradford JB, Fraver S, Palik BJ (2011) Forest management for mitigation and adaptation to climate change: insights from long-term silviculture experiments. Forest Ecol Manag 262(5):803-816.

De Simon G, Alberti G, Delle Vedove G, Zerbi G, Peressotti A (2012) Carbon stocks and net ecosystem production changes with time in two Italian forest chronosequences. Eur J Forest Res 131(5):1297-1311.

de Vries W, Reinds GJ, Gundersen P, Sterba H (2006) The impact of nitrogen deposition on carbon sequestration in European forests and forest soils. Global Change Biology 12(7):1151-1173.

Development Core Team R (2016) R: A language and environment for statistical computing. R Foundation for Statistical Computing, Vienna.

Dittmar C, Zech W, Elling W (2003) Growth variations of common beech (Fagus sylvatica $\mathrm{L}$.) under different climatic and environmental conditions in Europe - a dendroecological study. Forest Ecol Manag 173(1-3):63-78.

Duncker PS, Barreiro SM, Hengeveld GM, Lind T, Mason WL, Ambrozy S, Spiecker H (2012) Classification of Forest Management Approaches: A New Conceptual Framework and Its Applicability to European Forestry. Ecology and Society 17(4).

Enquist BJ, Niklas KJ (2002) Global allocation rules for patterns of biomass partitioning in seed plants. Science 295(5559):1517-1520.

Erb KH, Kastner T, Plutzar C, Bais ALS, Carvalhais N, Fetzel T, Gingrich S, Haberl H, Lauk C, Niedertscheider M, Pongratz J, Thurner M, Luysaaert S (2018)
Unexpectedly large impact of forest management and grazing on global vegetation biomass. Nature 553(7686):73-76.

Fahey TJ, Woodbury PB, Battles JJ, Goodale CL, Hamburg SP, Ollinger SV, Woodall CW (2010) Forest carbon storage: ecology, management, and policy. Front Ecol Environ 8(5):245-252.

Fichtner A, Sturm K, Rickert C, Härdtle W, Schrautzer J (2012) Competition response of European beech Fagus sylvatica L. varies with tree size and abiotic stress: minimizing anthropogenic disturbances in forests. J Appl Ecol 49(6):1306-1315.

Garcia-Gonzalo J, Peltola H, Briceno-Elizondo E, Kellomäki S (2007) Changed thinning regimes may increase carbon stock under climate change: a case study from a Finnish boreal forest. Clim Chang 81(3):431-454.

Granier A, Breda N, Longdoz B, Gross P, Ngao J (2008) Ten years of fluxes and stand growth in a young beech forest at Hesse, North-Eastern France. Ann For Sci 65(7):704-716.

Goodale CL, Apps MJ, Birdsey RA, Field CB, Heath LS, Houghton RA, Jenkins JC, Kohlmaier GH, Kurz W, Liu S, Nabuurs GJ, Nilsson S, Shvidenko AZ (2002) FOREST CARBON SINKS IN THE NORTHERN HEMISPHERE. Ecological Applications 12(3):891-899.

Hall GMJ, Wiser SK, Allen RB, Beets PN, Goulding CJ (2001) Strategies to estimate national forest carbon stocks from inventory data: the 1990 New Zealand baseline. Global Change Biology 7(4):389-403.

Hemery GE (2008) Forest management and silvicultural responses to projected climate change impacts on European broadleaved trees and forests. Int For Rev 10(4):591-607.

Herbst M, Mund M, Tamrakar R, Knohl A (2015) Differences in carbon uptake and water use between a managed and an unmanaged beech forest in Central Germany. Forest Ecol Manag 355:101-108.

Hessenmöller D, Bouriaud O, Fritzlar D, Elsenhans AS, Schulze E-D (2018) A silvicultural strategy for managing uneven-aged beech-dominated forests in Thuringia, Germany: a new approach to an old problem. Scand J Forest Res 33(7):668-680

Jucker T, Avăcăriței D, Bărnoaiea I, Duduman G, Bouriaud O, Coomes DA (2015) Climate modulates the effects of tree diversity on forest productivity. J Ecol 104(2):388-398.

Jucker T, Bouriaud O, Avacaritei D, Dănilă I, Duduman G, Valladares F, Coomes DA (2014) Competition for light and water play contrasting roles in driving diversity-productivity relationships in Iberian forests. J Ecol 102(5):1202-1213.

Juodvalkis A, Kairiukstis L, Vasiliauskas R (2005) Effects of thinning on growth of six tree species in north-temperate forests of Lithuania. Eur J Forest Res 124: 187-192.

Kahl T, Arnstadt T, Aber K, Bässler C, Bauhus J, Borken W, Buscot F, Floren A, Heigl C, Hessenmöller D, Hofrichter M, Hoppe B, Kellner H, Krüger D, Linsenmair K, Mazner E, Otto P, Purahng W, Seilwinder C, Schulze E-D, Wende B, Weisser W, Gossner W (2017) Wood decay rates of 13 temperate tree species in relation to wood properties, enzyme activities and organismic diversities. Forest Ecol Manag 391:86-95.

Keeling HC, Phillips OL (2007) The global relationship between forest productivity and biomass. Glob Ecol Biogeogr 16(5):618-631.

Koenker R (2017) quantreg: Quantile regression. R package version 5.21. https:// CRAN.Rproject.org/package $=$ quantreg. .

Kunstler G, Albert CH, Courbaud B, Lavergne S, Thuiller W, Vieilledent G, Zimmermann N, Coomes DA (2011) Effects of competition on tree radialgrowth vary in importance but not in intensity along climatic gradients. J Ecol 99(1):300-312.

Lafond V, Lagarrigues G, Cordonnier T, Courbaud B (2014) Uneven-aged management options to promote forest resilience for climate change adaptation: effects of group selection and harvesting intensity. Ann For Sci 71(2):173-186.

Le Goff N, Ottorini J-M (1999) Effects of thinning on beech growth. Interaction with climatic factors. Rev Forest Fr 51:355-364.

Luyssaert S, Hessenmöller D, von Lüpke N, Kaiser S, Schulze E-D (2011) Quantifying land-use and disturbance intensity in forestry, based on the selfthinning relationship. Ecol Appl 21:3272-3284.

Matthews JD (1989) Silvicultural systems. Oxford University Press, Oxford, p 284.

McKinley DC, Ryan MG, Birdsey RA, Giardina CP, Harmon ME, Heath LS, Houghton RA, Jackson RB, Morrison JF (2011) A synthesis of current knowledge on forests and carbon storage in the United States. Ecol Appl 21(6):1902-1924.

Mund M (2004) Carbon pools of European beech forests (Fagus sylvatica) under different silvicultural management. Dissertation, Berichte des Forschungszentrums Waldö kosysteme. Forschungs-zentrum Waldökosysteme, Göttingen. 
Mund M, Schulze E-D (2006) Impacts of forest management on the carbon budget of European beech (Fagus sylvatica) forests. Allg Forst Jagdztg 177: 47-63.

Nabuurs GJ, Päivinen R, \& Schanz H (2001) Sustainable management regimes for Europe's forests-a projection with EFISCEN until 2050. Forest Policy and Economics 3(3-4):155-173.

Naudts K, Chen Y, McGrath MJ, Ryder J, Valade A, Otto J, Luyssaert S (2016) Europe's forest management did not mitigate climate warming. Science 351(6273):597-600

Nave LE, Vance ED, Swanston CW, Curtis PS (2010) Harvest impacts on soil carbon storage in temperate forests. Forest Ecol Manag 259(5):857-866.

Netzer F, Schmid C, Herschbach C, Rennenberg H (2017) Phosphorus-nutrition of European beech (Fagus sylvatica L.) during annual growth depends on tree age and P-availability in the soil. Environ Exp Bot 137:194-207.

Noormets A, Epron D, Domec JC, McNulty SG, Fox T, Sun G, King JS (2015) Effects of forest management on productivity and carbon sequestration: a review and hypothesis. Forest Ecol Manag 355:124-140.

Nunery JS, Keeton WS (2010) Forest carbon storage in the northeastern United States: net effects of harvesting frequency, post-harvest retention, and wood products. Forest Ecol Manag 259(8):1363-1375.

Pan Y, Birdsey RA, Fang J, Houghton R, Kauppi PE, Kurz WA, Phillips OL, Shvidenko A, Lewis SL, Canadell GJ, Ciais P, Jackson RB, Pacala SW, McGuire AD, Piao S, Rautiainen A, Sitch S, Hayes D (2011) A Large and Persistent Carbon Sink in the World's Forests. Science 333(6045):988-993.

Peters R (1997) Beech forests. Geobotany, vol 24. Kluwer, Dordrecht. 169 pp.

Petrițan AM, Bouriaud O, Frank DC, Petrițan IC (2017) Dendroecological reconstruction of disturbance history of an old-growth mixed sessile oakbeech forest. J Veg Sci 28(1):117-127.

Pilegaard K, Ibrom A, Courtney MS, Hummelshøj P, Jensen NO (2011) Increasing net $\mathrm{CO}_{2}$ uptake by a Danish beech forest during the period from 1996 to 2009. Agric For Meteorol 151(7):934-946

Pouderoux S, Deleuze C, Dhôte J-F (2001) Analyse du rendement des houppiers dans un essai d'éclaircie de hêtre grâce à un modèle a base écophysiologique. Ann For Sci 58(3):261-275.

Pretzsch H (2005) Stand density and growth of Norway spruces (Picea abies (L.) karst) and European beech (Fagus sylvatica L.): evidence from long-term experimental plots. Eur J Forest Res 124:193-205.

Pretzsch H (2009) Forest dynamics, growth and yield: from measurement to model. Springer Verlag, Berlin Heidelberg.

Pretzsch H (2014) Canopy space filling and tree crown morphology in mixedspecies stands compared with monocultures. Forest Ecol Manag 327:251-264.

Purahong W, Hoppe B, Kahl T, Schloter M, Schulze E-D, Bauhus J, Buscot F, Krüger D (2014) Changes within a single land-use category alter microbial diversity and community structure: molecular evidence from wood-inhabiting fungi in forest ecosystems. J Environ Manag 139:109-119.

Reineke LH (1933) Perfecting a stand-density index for even-aged forests. J Agric Res 46:627-638.

Reyer C, Lasch-Born P, Suckow F, Gutsch M, Murawski A, Pilz T (2014) Projections of regional changes in forest net primary productivity for different tree species in Europe driven by climate change and carbon dioxide. Ann For Sci 71:211-225. https://doi.org/10.1007/s13595-013-0306-8.

Schaedel MS, Larson AJ, Affleck DL, Belote RT, Goodburn JM, Page-Dumroese DS (2017) Early forest thinning changes aboveground carbon distribution among pools, but not total amount. Forest Ecol Manag 389:187-198.

Schall P, Ammer C (2013) RETRACTED ARTICLE: Quantifying forest stand management intensity in Central European forests. European Journal of Forest Research 132(2):397-397.

Scharnweber T, Manthey M, Criegee C, Bauwe A, Schröder C, Wilmking M (2011) Drought matters-declining precipitation influences growth of Fagus sylvatica L. and Quercus robur L. in North-Eastern Germany. Forest Ecol Manag 262(6): 947-961.

Schlamadinger B, Apps M, Bohlin F, Gustavsson L, Jungmeier G, Marland G, Pingoud K, Savolainen I (1997) Towards a standard methodology for greenhouse gas balances of bioenergy systems in comparison with fossil energy systems. Biomass and Bioenergy 13(6):359-375.

Schulze E-D, Bouriaud L, Bussler H, Gossner M, Walentowski H, Hessenmöller D, Bouriaud O, Gadow KV (2014) Opinion paper: Forest management and biodiversity. Web Ecology 14(1):3.

Schulze ED (2018) Effects of forest management on biodiversity in temperate deciduous forests: An overview based on Central European beech forests. Journal for Nature Conservation 43:213-226.
Schulze E-D, Bouriaud O, Weber U, Roscher C, Hessenmöller D (2018a) Management beaks the natural productivity-biodiversity relationship in forests and grassland: an opinion. Forest Ecosyst 5:3.

Schulze E-D, Körner C, Law BE, Haberl H, Luyssaert S (2012) Large-scale bioenergy from additional harvest of forest biomass is neither sustainable nor greenhouse gas neutral. GCB Bioenergy 4(6):611-616.

Skovsgaard JP, Vanclay JK (2008) Forest site productivity: a review of the evolution of dendrometric concepts for even-aged stands. Forestry 81(1):13-32.

Sousa-Silva R, Verbist B, Lomba Â, Valent P, Suškevičs M, Picard O, Hoogstra-Klein MA, Cosofret VC, Bouriaud L, Ponette Q, Verheyen K (2018) Adapting forest management to climate change in Europe: linking perceptions to adaptive responses. Forest Policy Econ 90:22-30.

Thornley JHM, Cannell MGR (2000) Managing forests for wood yield and carbon storage: a theoretical study. Tree Physiol 20(7):477-484.

van der Maaten E (2013) Thinning prolongs growth duration of European beech (Fagus sylvatica L.) across a valley in southwestern Germany. Forest Ecol Manag 306(15):135-141.

Wallentin C, Nilsson U (2011) Initial effect of thinning on stand gross stemvolume production in a 33-year-old Norway spruce (Picea abies (L.) karst.) stand in southern Sweden. Scand J Forest Res 26(S11):21-35.

Woodall CW, Walters BF, Oswalt SN, Domke GM, Toney C, Gray AN (2013) Biomass and carbon attributes of downed woody materials in forests of the United States. Forest Ecology and Management 305:48-59.

Wutzler T, Wirth C, Schumacher J (2008) Generic biomass functions for common beech (Fagus sylvatica) in Central Europe: predictions and components of uncertainty, Can J For Res 38(6):1661-1675.

Zeide B (2001) Resolving contradictions in forestry: back to science. Forestry Chron 77(6):973-981.

Zeide B (2005) How to measure stand density. Trees 19:1-14.

Zhou D, Zhao SQ, Liu S, Oeding J (2013) A meta-analysis on the impacts of partial cutting on forest structure and carbon storage. Biogeosciences 10 3691-3703.

\section{Submit your manuscript to a SpringerOpen ${ }^{\odot}$ journal and benefit from:}

- Convenient online submission

- Rigorous peer review

- Open access: articles freely available online

High visibility within the field

- Retaining the copyright to your article

Submit your next manuscript at $>$ springeropen.com 